INDEPENDENT JOURNAL OF MANAGEMENT \& PRODUCTION (IJM\&P)

\title{
APPLIED KNOWLEDGE MANAGEMENT IN SMALL DESIGN FIRMS: CASE STUDY
}

\author{
Christian Donin \\ Universidade Federal de Santa Maria, Brazil \\ E-mail: donin@unisc.br
}

Eduardo Rizzatti Universidade Federal de Santa Maria, Brazil E-mail: edu_rizzatti@yahoo.com.br

Karin Geiger CD Engenharia LTDA, Brazil E-mail: karin@cdonin.com.br

Tatiane Sartori Universidade Federal de Santa Maria, Brazil E-mail: tatianesartori@yahoo.com.br

Submission: 04/03/2016

Revision: $17 / 03 / 2016$

\section{ABSTRACT}

Accept: 24/03/2016

Knowledge is the new strategic imperative of organizations. The ability to manage knowledge is a crucial part of any organizations operational processes. The creation and diffusion of knowledge have become ever more important factors in competitiveness. This paper investigates the Knowledge Management and flow information and in small design firms. It is divided into three main parts. The first part of this paper describes the importance of Knowledge Management for organizations are described together with responsibilities needed to ensure successful Knowledge Management implementations and the Spiral of Organizational Knowledge Creation conception. The second part approaches literature available about process and organizational structure and information flow related to Brazilian design firms. Finally, this paper presents a case study of small design office of Civil Engineering identifying organizational process, verifying the types of 
communication practices and identifying the types of dynamic process of The Spiral of Organizational Knowledge Creation, KM strategy and dynamic through Knowledge Transfer.

Keywords: knowledge management, organizational process, information flow, design firms

\section{INTRODUCTION}

There is no universally accepted definition of Knowledge Management, but there are numerous definitions. Putting it concise, it is the process through which organizations generate value from their intellectual and knowledge based assets. Knowledge management starts with data, a mere collection of data is not information. It is needed context and understanding to transform a data to information, knowledge and wisdom. Information constitutes a set of meaningful data, which is the result of data transformation into something that can be understood either through a specific context (NODARI et al. 2015). It is important to note the differences between the two types of knowledge as defined at Spiral of organizational knowledge creation.

\section{THE SPIRAL OF ORGANIZATIONAL KNOWLEDGE CREATION}

Theory defined two types of knowledge: tacit knowledge and explicit knowledge. Tacit knowledge is hard to formalize and communicate. Explicit knowledge is transmittable in formal and systematic language. Knowledge can be explicit, which lends itself to transfer strategies such as formal desk manuals, procedures, and other codified processes. Knowledge can also be tacit, which lends itself to transfer strategies such as mentoring, coaching, communities of practice and the like. Explicit knowledge is more easily quantified and qualified, and can thus be more readily captured. Tacit knowledge, however, involves soft skills, personal characteristics, development of cooperative partnerships, and subjective situational judgments. As this type of knowledge is more intuitive in nature and derived from experience, it is less readily distilled and captured into orderly process structures. Although, tacit knowledge (unstructured) must be combined with explicit knowledge (structured) for retaining and developing documents and best practice.

The words explicit and tacit can be misleading because they imply that they are exclusive. However, according to Omotayo (2015) explicit knowledge is "grounded" in tacit knowledge and is created by externalization (visualization, 
INDEPENDENT JOURNAL OF MANAGEMENT \& PRODUCTION (IJM\&P)

DOI: 10.14807/ijmp.v7i3.444

articulation, or codification) of tacit knowledge. Explicit knowledge is the part of tacit knowledge that can be expressed verbally and does not represent the entire body of knowledge. This process is the key to organizational knowledge creation. This interaction between them is called four modes of knowledge conversion: Socialization, Externalization, Combination, and Internalization:

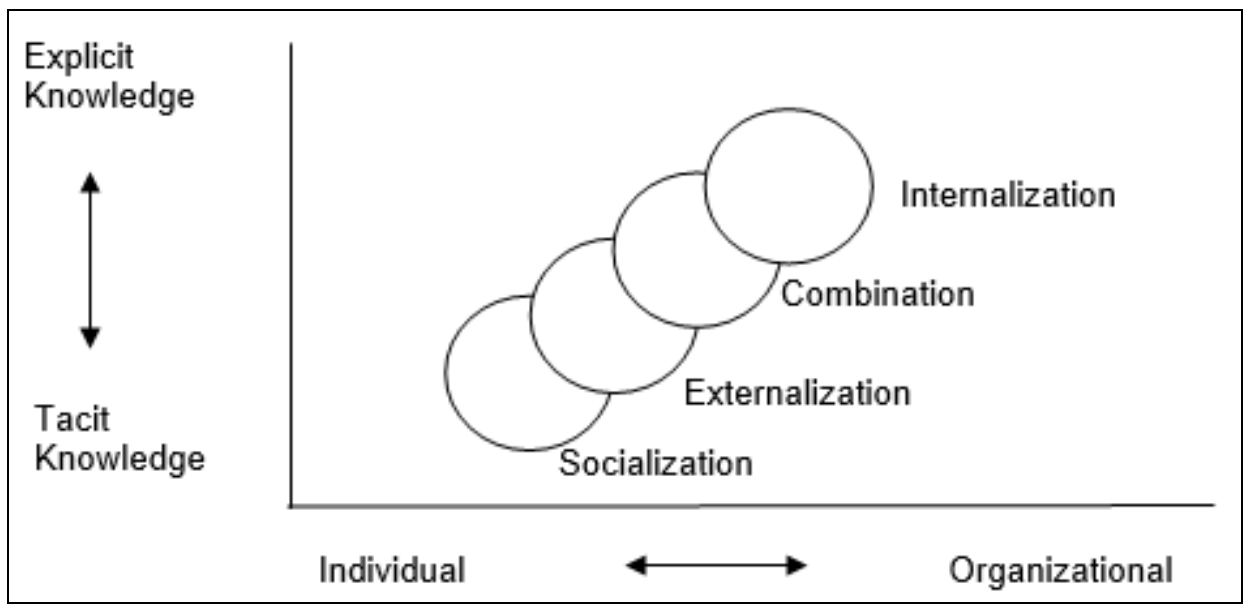

Figure 1. Spiral of Organizational Knowledge Creation.

(a) Socialization is a process of creating common tacit knowledge through shared experiences at the same time, thereby creating common unarticulated beliefs or embodied skills, from individual tacit knowledge to group tacit knowledge. (b) Externalization (from tacit knowledge to explicit knowledge) is a process of combined tacit knowledge and explicit knowledge e.g. creating a new product. (c)Combination (from separate explicit knowledge to systemic explicit knowledge) is a process of assembling new and existing explicit knowledge into a systemic knowledge, such as a set of specifications for a prototype of a new product. (d) Internalization is a process of articulating explicit knowledge into tacit, operational knowledge such as know-how. Explicit knowledge documented into text. In order to apply the Spiral of Organizational Knowledge Creation.

Summarizing and placing this concept into process, organizational knowledge starts at the individual level with thoughts or understanding (internalization). It moves upwards through socialization, where individuals dialogue with team. The ideas are articulated (externalization) and become more widespread through diffusion of explicit knowledge (combination). As knowledge moves up the spiral knowledge is more widely spread and the spiral gets wider. In another hand, it happens when individuals access organizational knowledge, they apply it and internalize new 
DOI: 10.14807/ijmp.v7i3.444

knowledge, thus setting the stage for an enhanced piece of knowledge to work its up the spiral.

In order to approach small design firms about Knowledge Management (KM) based on the Spiral of Organizational Knowledge Creation, the organizational process needs to be clarified. According to Bolisani, Scarso and Zieba (2015) KM is often considered to be a systematic and organized efforts to find, organize and make company's intellectual capital available. The intentional nature of $\mathrm{KM}$ is often associated with the notion of KM strategy: Emergent and Deliberate Knowledge Management.

Deliberate and planned KM approach where practices, tools and methods of managing knowledge are linked to the general static orientation of the company, are deliberately designed at a top management level, KM goals are based on a rational analysis of company's needs, objective and resources and are later implemented and spread across the company with deliberate efforts and investment.

Emergent KM approach where practices, tools and methods of managing knowledge originate from the daily practice and learning processes of company's employees develop their own methods of learning, storing, retrieving and sharing knowledge in relation to their actual needs and practical problems to solve. The methods and tools that prove to be effective, useful and/or compatible with the daily business practice are later development and become established practice, and later can be recognized as the KM approach of company.

Therefore, in order to add value process through reuse and innovation, it required to understand the KM strategy that involves resources (organization's people, technology, processes) and organizational structure.

\section{THE ORGANIZATIONAL PROCESS AND INFORMATION FLOW AND STORING THE INFORMATION}

This chapter approaches literature available about process and organizational structure and information flow related to Brazilian design firms. Although KM have become the focus of extensive investigation, not many studies applied to Brazilian design firms. Many studies breaks project into operations: inputs (information), process, and outputs (qualified information). Jobim (1999) showed in details the way the data and the production of information / knowledge within the design office 
DOI: 10.14807/ijmp.v7i3.444

routine. It presents below scheme of organizational process and definition of each step:

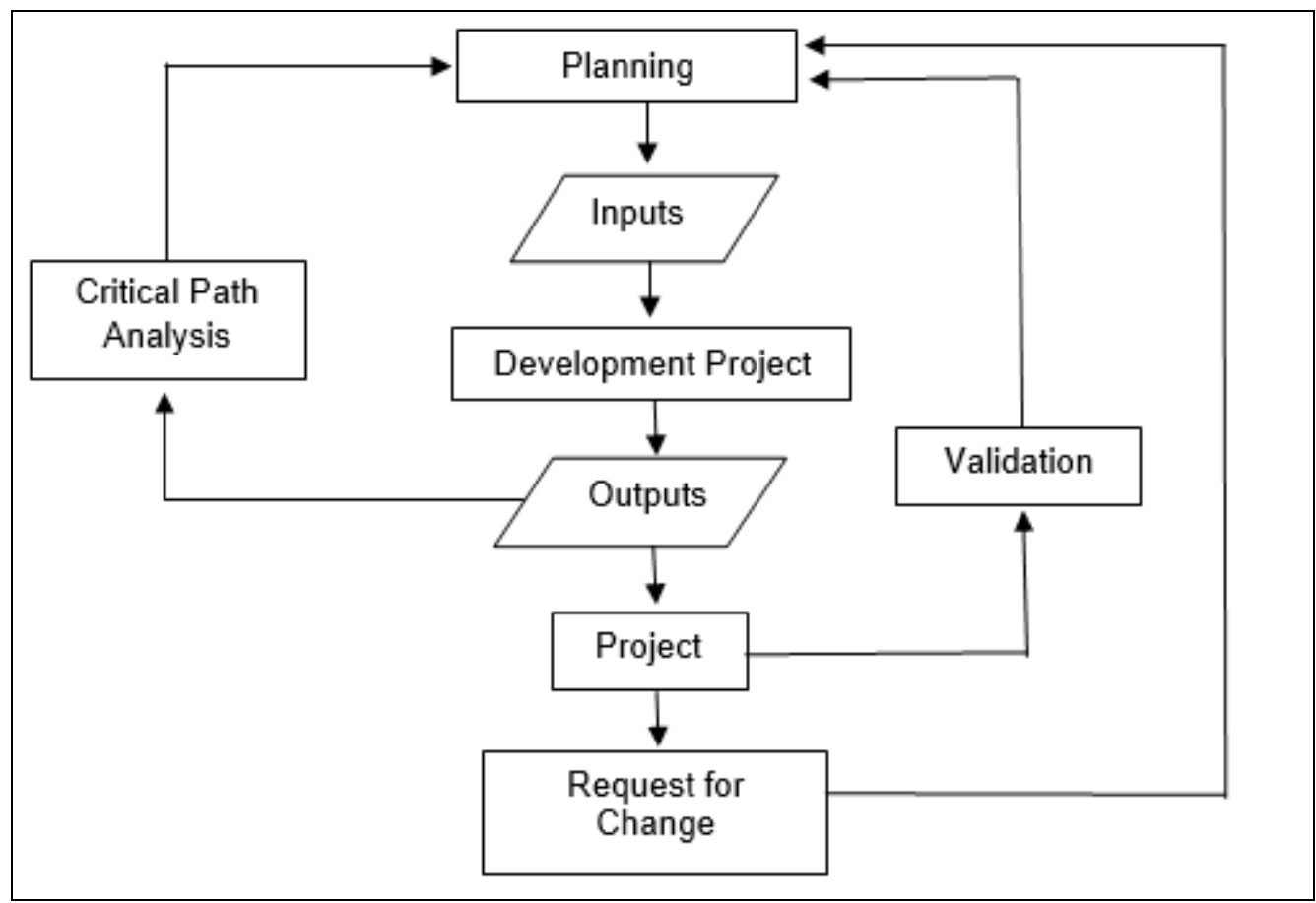

Figure 2. Organization Process in design firms. Source: adapted from Jobim (1999).

a) Planning expresses the objectives and requirements of the project in terms of project scope, project schedule, resource requirement, project cost estimation. b) Inputs are those data use in the project to implement it. c) Execution / Development. d) Outputs. Outputs are the direct immediate term results associated with a project.

Projects will produce two kinds of outputs. One kind are the intangible things the project intends to produce: e.g., a training program to develop or refresh job skills. The other kinds of outputs are tangible plans, measurements, tracking processes and status reports that pertain to planning, managing and closing the project itself. e) Critical Path Method.

The essential technique for using Critical Path Method is to construct a model of the project that includes: a list of all activities required to complete the project, prioritize activities for the effective management and to shorten the planned critical path of a project. Critical path is the sequence of activities that add up to the longest overall duration. It is the shortest time possible to complete the project. Any delay of an activity on the critical path directly impacts the planned project completion date (there is no float on the critical path). 
DOI: 10.14807/ijmp.v7i3.444

A project can have several, parallel, near critical paths. An additional parallel path through the network with the total durations shorter than the critical path is called a sub-critical or non-critical path.

After it defined the information tack, here it is presented the main communication practices. Muszynska (2015) described types of communication practices included: a) in person, face-to-face communication, b) e-mail - used mostly for record-keeping and follow-up potential, the importance of the matter, getting other people involved, sending Internet links or files, and sending/receiving background information; c) phone calls; d) instant messaging; e) database - for sharing blueprints.

Sousa (2010) observed the same communication practices (except texting message/ instant messaging) in Brazilian architectures offices. According the author storing the information that are captured or shared through: forms, books, manuals and blueprints (writing information); digital files, e-mails (digital information). She divided in formal and informal communication. The formal communication uses structured processes following standards.

Sousa (2010) mentioned that, although informal communication are less emphasized in project management processes often contribute decisively to the success of the process. In most organizations, the bulk of information is likely to be in relatively unstructured formats. These can be in the form of typical business or office documents such as reports, memos, spreadsheets or emails. These documents normally contain valuable information but they are not easily searched and found. For a Knowledge Management system to be effective, it must provide for search engines that can deal with such unstructured information.

Based on Tribelsky and Sacks (2010 b) main options for storing the information in design firm during the dynamic process depends on: a) an information package is a view in a drawing, a text document, worksheet or data table, a page of calculations, etc., whether on a printed page or in a computer file. Information packages are the basic units that are transferred between design project team members. b) an information item is a single piece of information.

It may be textual (a label or dimension on a drawing, a clauses in a specification) or graphic (a line, arc or hatching in a drawing). An information 
DOI: 10.14807/ijmp.v7i3.444

package therefore represents a set of information items. c) an information object is a distinct component of a building or facility with technical and engineering attributes and characteristics.

Objects are defined as having form, function and behavior, such as ceilings, windows, pipes, walls, beams, etc. d) an information attribute is a technical, engineering or management attribute of an information object such as its dimensions, material type, supplier name etc. The value of an information attribute may be displayed in any number of information packages. Tribelsky and Sacks (2010b) provide a set of measures and indexes designed to assist in quantifying information flow during the design process. Data collection are based on information transactions registered in the journal logs of the project intranet software and on the outcomes of the process analyses.

Controlling data without software is unfeasible, and do it by using software is not common because a low number of companies use it. Building Information Modelling (BIM) is well-known, but its use is quite limited in Brazil. Souza and Amorim (2009) developed a research about using of BIM in Brazilian architectural offices, total thirteen offices was selected and they considered a representative sample of the total offices that uses this technology in Brazil.

The forefront of implementing the BIM systems in the early 2000s and the transition from CAD to BIM requires a number of adjustments. The barriers for adopting: time for implementation, cost of software and investments in hardware to support the software, training. Cost as an issue, not just in Brazil, according to Ogbeide (2010) as always the financial aspect is an obstacle when it comes to new innovations, BIM tools are not different in this sense. Since about $70 \%$ of the design firms are small scale companies they will have problem finding funds to finance BIM technology and implementing BIM in design phase.

Permonian and Marques Neto (2015) and Stehling (2012) observed that Auto Cad Software is used in all offices in their studies. They indicates that, the use of software that can be able to connect with BIM files is a key technology for the projects as ArchiCad, Revit, Microstation, Tekla Structures, Smartplant3D, Proengeneer, Inventor, AutoCad, Naviwork, Autoplant, 3D max, Civil 3d, Solidworks, Sketchup, Vectorworks, CypeCad, TQS. Permonian and Marques Neto (2015) 
DOI: 10.14807/ijmp.v7i3.444

concluded that $33 \%$ starting use BIM, however just $11 \%$ development the design on it. Most companies use the BIM only for 3D project view. Stehling (2012) observed that the BIM concept is associated with the simple use of software, excluding its use for the project management process.

There is a study showing correlation between characteristics of information flow including design team members and the degree of success achieved in the detailed design phase of civil engineering projects. The information flows were characterized in terms of measures drawn from the concepts of lean thinking, such as flow bottlenecks, rework, large batches and cycle time, which were monitored and computed analytically using a set of information flow indices.

The degree of success was measured in terms of the effectiveness of the design documents that were produced, the projects' success or failure in meeting targets of budget, schedule and client expectations, and supplemented by subjective assessments collected in interviews with key personnel from all the projects. The results show a direct empirical relationship between the objective measures of information flow and the measures of the effectiveness of design documents.

Stable information flow with lower occurrence of flow interruption phenomena correlated reasonably well with higher quality design documents. Similarly, the degree to which projects vary in terms of meeting budget and schedule targets appears to correlate with the frequency of occurrence of phenomena that indicate disruption of smooth information flows (TRIBELSKY; SACKS, 2010a).

Therefore, it is concluded from Tribelsky and Sacks study based on the Spiral of Organizational Knowledge Creation that the project's success level is positively related to documentation created by it, thus as more like Internalization, more successful will be the project.

Firms have been looking for Internalization, proving it, according to Tribelsky and Sacks (2010a), it is growing number of engaged offices in quality programs, that requires structured process with documentation, however it is increasing the number of research showing that there are few offices successfully apply the quality program methodology. Most offices have non-systematic process management; the lack of participation of engineers in the design stage; the lack of evaluation of designers. 
INDEPENDENT JOURNAL OF MANAGEMENT \& PRODUCTION (IJM\&P)

http://www.ijmp.jor.br

v. 7, n. 3, July - September 2016

ISSN: 2236-269X

DOI: 10.14807/ijmp.v7i3.444

Inefficient flows of information result in reworking follows wherever design has proceeded on basis of outdated versions of other designers' drawings because newer information was not forthcoming and overall project durations are extended and increasing costs. Unfortunately, the flow of information in dispersed design teams is not well understood, therefore it is frequently not managed well. Understanding the process by with information flows between project participants is essential to improvement of design management (TRIBELSKY; SACKS, 2010a).

There is consensus that the communications management has the main problems of project management of Engineering and Architecture design firms. Most offices do not have any knowledge of the techniques and good project management practices. (COSTA JR. 2014).

Scherer, L. J.; Kirsten, T. ; Santos, A. (2015) the managers of projects identified that communication is not the strong point of the organization, recognized failures due to problems in communication and they present concerns with collect and storage information. According to Lopes et al (2002) lack communication and inadequate registration information or even total absence are common practices in design firms. There are documents with recorded information; generally, required files by customer and additional designers. In addition, authors affirm that the information flow in their case study reflects the usual company process in most Architecture Firms in Brazil.

Model is widely based on the professional experience. Based on it, small design process is a process of assembling new and existing explicit knowledge, it result in new product/design, developed solution for each specific project. Therefore, even Internalization process presents best result; Combination describes the most dynamic process in design firms.

\section{APPLIED KNOWLEDGE MANAGEMENT : CASE STUDY}

In order to applied knowledge management on small design office of Civil Engineering as case study. This office develops just one complementary modality of design. The methodology is based on theory presented in this paper. Observing Jobim (1999) scheme of organizational process, looked for adapting for study case company in order to identify the trajectory information to knowledge. 
INDEPENDENT JOURNAL OF MANAGEMENT \& PRODUCTION (IJM\&P)

http://www.ijmp.jor.br

v. 7, n. 3, July - September 2016

ISSN: 2236-269X

DOI: 10.14807/ijmp.v7i3.444

Firstly, verify the types of communication practices on office case study routine base on Muszynska (2015). Later, considering Sousa (2010), communication was divided in formal or informal. Identifying the types of dynamic process of The Spiral of Organizational Knowledge Creation, KM strategy and dynamic through Knowledge Transfer. Finally, it was selected 10 clients/design offices that working as partner on projects, in order to verifying BIM use dissemination.

After created an organization process scheme (Figure 2), the following communication practices has been identified, the most used to least used: phone calls, e-mail, face-to-face communication, database and instant messaging. Instant messaging is still less often, but it has been increased during last two years. In order to compare, six in ten clients send instant messaging in 2015; one in ten clients send instant messaging in 2008.

Table below presents evaluation procedures of case study office as Formal and Informal. Therefore, looking for clarifying if the procedure is formal or informal, it was defined as informal procedure: unformatted note, subjective and verbal. Formatted document as formal.

Table 1. Classification of Information flow about company's procedures.

\begin{tabular}{|l|l|l|}
\hline Procedure & Input & Output \\
\hline Client demand & Client (informal) & Unformatted note (informal) \\
\hline $\begin{array}{l}\text { Service Proposal } \\
\text { /contract }\end{array}$ & Adm. (informal) & Contract (formal) \\
\hline Data collection & $\begin{array}{l}\text { Blueprint and additional } \\
\text { documents (formal) }\end{array}$ & $\begin{array}{l}\text { Blueprint and additional documents } \\
\text { (formal) }\end{array}$ \\
\hline Project & $\begin{array}{l}\text { Blueprint (formal) additional } \\
\text { Technical notes (informal) }\end{array}$ & $\begin{array}{l}\text { Blueprints and acuments (formal) } \\
\text { docum a }\end{array}$ \\
\hline
\end{tabular}

Based on presented studies, theory of Knowledge Management and a Civil Engineering small design firm as case study. It is developed Flowchart of Information Flows in design process with identification of dynamic process. The process starts with first contact with client by phone for scheduling a meeting.

Meeting is a gathering of firm agent and client that has been scheduled for the purpose of client presents his/her demand. It is a short meeting. This step is classified of Socialization, involving just tacit knoledge and just tacit knoledge, in the both sides. If the demand is interesting for the office the next step is collecting all needed information for preparing a budget. 
DOI: 10.14807/ijmp.v7i3.444

If the office is not interested in development the project, the demand is rejected. Construction projects involving diferent modalities of designs. This office develops just one modality of design, when it is offered a demand out of office scope, the office indicates others professionals.

These professionals often work together on different projects, so different professionals synergistically combine their efforts so that their final product are delivered in a more efficient and effective manner than when each area works independently from the other. Each professional/office is expert in a particular modality. Defining if the demand is in the scope or not is of articulating explicit knowledge into tacit knowledge, therefore it is an Internalization. Documents as a contract is created during this process.

The following steps, it was approached above Planning, Inputs, Development Project, next step is Outputs. Outputs are all results associated with a project, including the final design. Finally, the project is approved or not. If it is approved, the process is complete. When the project is not approved or there is a request for change, next step is Critical Path Analysis followed by Planning.

Critical Path Analysis is based on Critical Path Method, it was explained previously in this paper. This step is Combination, a process of assembling new and existing explicit knowledge into a systemic knowledge, resulting in a personalized product/design. 
INDEPENDENT JOURNAL OF MANAGEMENT \& PRODUCTION (IJM\&P)

http://www.ijmp.jor.br

v. 7, n. 3, July - September 2016

ISSN: 2236-269X

DOI: 10.14807/ijmp.v7i3.444
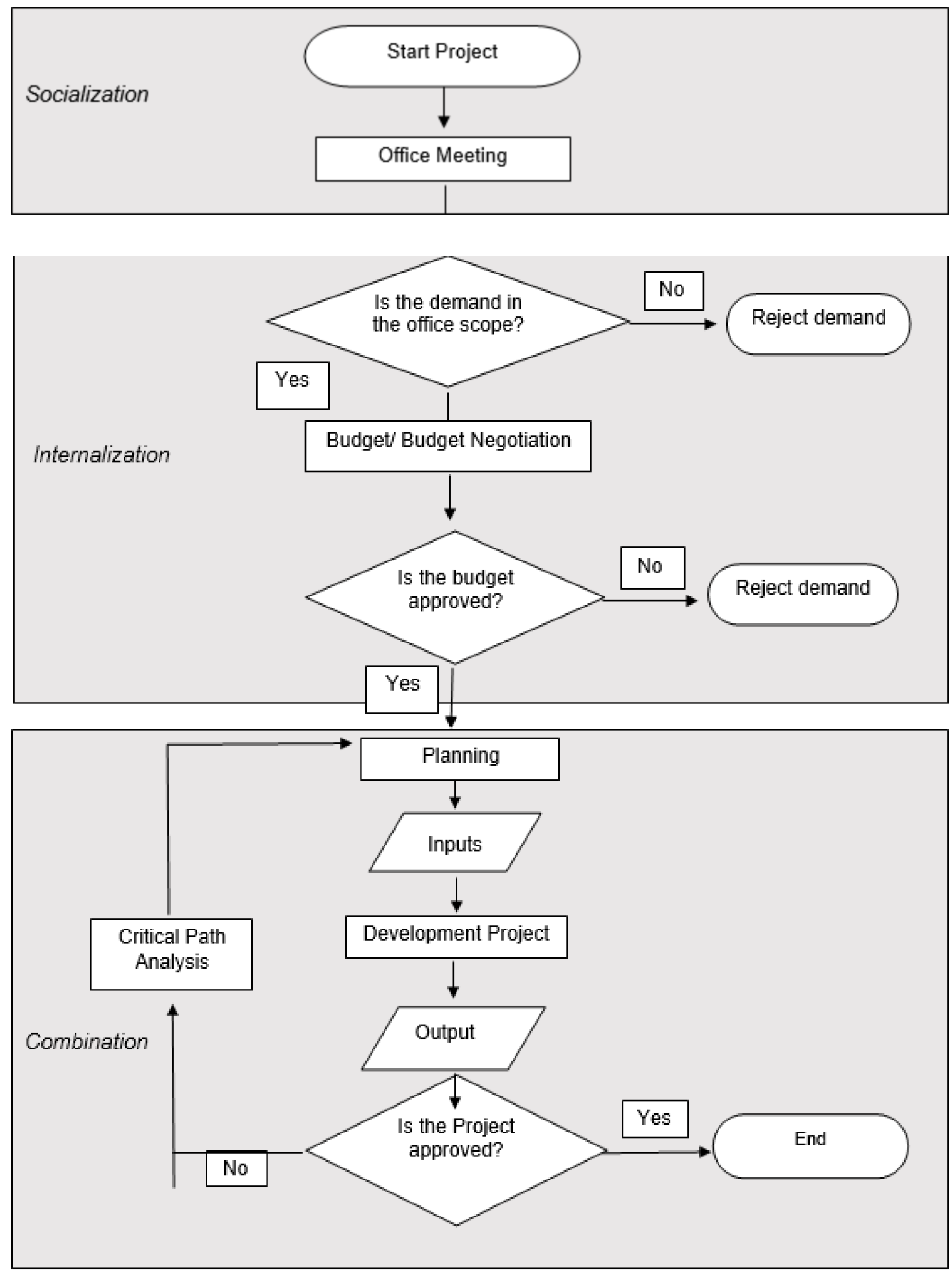

Figure 3: Information Flows in design process in the Civil Engineering office 
INDEPENDENT JOURNAL OF MANAGEMENT \& PRODUCTION (IJM\&P)

http://www.ijmp.jor.br

v. 7, n. 3, July - September 2016

ISSN: 2236-269X

DOI: 10.14807/ijmp.v7i3.444

Therefore, each project involve three types of dynamic process of The Spiral of Organizational Knowledge Creation: Socialization, Internalization, Combination. Also, it must to considering during the organizational knowledge that individuals access organizational knowledge, they apply it and internalize new knowledge, thus contributing to creating new knowledge as spiral. Firms have been looking for Internalization during all their activities that requires structured process with documentation.

Finally, it is expected capturing the value of the dynamic through knowledge transfer. Considering Civil Engineering small design firm, the learned process in each step of project: a) Define the Project. This step is the initial step wherein the process and team. Initial engagement from all key players should be established in advance of the project. Select staff with specific expertise or knowledge of the project. This phase is complete with success for case study office considering assembling the team. b) Collect. The collection process involves the capture of information through structured and unstructured processes such as project critiques, written forms, and meetings. Case study company complete this step partially, it collects needed information for project execution, however there are no standard check-list with all documents, so capturing of information through unstructured processes. c) Verify. This process serves to verify the accuracy and applicability of activities submitted. Domain or subject matter experts may be involved in coordinating and conducting reviews (Critical Path Analysis). Depending of outputs study case company executes this step through unformatted note.

Note that in the case study's office tries to assemble same group of professionals for projects, they realized that involve the same professionals it can help optimize project's performance. However, this is common this company combines different teams during period project time. The relationships and varying input from architects, engineering consultants, contractors. Also, they did not collect information after the end of project, therefore it is a gap in knowledge transfer. It is not an exception, common practice in this field based one following authors.

Team members should meet regularly to capture lessons learned, it is also helpful to bring together the project team and the end of or during a project (WHITE; COHAN, 2016). The lessons learned in knowledge generated during the design 
INDEPENDENT JOURNAL OF MANAGEMENT \& PRODUCTION (IJM\&P)

http://www.ijmp.jor.br

v. 7, n. 3, July - September 2016

ISSN: 2236-269X

DOI: 10.14807/ijmp.v7i3.444

review process may be stored in a portable document file format, identifying effective management practices (DESHPANDEA et al 2014).

Kamara et al. (2002) emphasized problems with post-project reviews that aim to capture lessons learned. It is a highly desirable activity but often does not occur for a number of reasons. Construction projects are of a temporary nature often involving multi-disciplinary and virtual teams. If they occur, lessons learned take place after the project completion when project participants have transferred to new projects and, because of the project duration, the time lag between a lesson being learned and recorded is lengthy and thus may be lacking in detail. There is a problem noted on this case study related to design process. Design process often change because new requirements are added, or scheduled tasks have failed and it is needed to be repeated or replaced with complex procedures.

Software with controlling data or able to make connection with it, it is helpful tool for creating conditions for development formal documents and post-project evaluation. As BIM is the well-known software and collecting data is a gap in this study case, in order to verifying BIM use dissemination it was selected 10 clients/design offices that working as partner on projects. Zero in ten use BIM for the project management process. Ten in ten use Auto Cad Software and a least one of softwares that can be able to connect with BIM (as ArchiCad, Revit, Microstation, Tekla Structures, Smartplant3D, Proengeneer, Inventor, Naviwork, Autoplant, 3D max, Civil 3d, Solidworks, Sketchup, Vectorworks, Cypecad, TQS). Sketchup is well know. The study case result about this topic is not an exception, similar result as Permonian and Marques Neto (2015) and Stehling (2012).

In mind Bolisani, Scarso and Zieba (2015) concept, company case study uses Emergent KM strategy. It approaches appears to be more flexible, but this flexibility may be not designed intentionally. Planning horizon short-term, scope action is local problems, medium level of familiarity with KM language. KM solutions survive of they are flexible and can change over time with company's needs.

\section{CONCLUSION}

This paper presents the trajectory information to knowledge in design process in the Civil Engineering office. About types of communication practices, nowadays instant messaging take a place on office routine. Undocumented procedures, lack 
communication resulting in gaps on capturing and transferring project knowledge. Problems with post-project reviews aim to capture lessons learned. BIM is well known, but use it is incipient especially in project management process. This case study is not an exception; most studies identified serious deficiencies in information flow in Brazilian design firms.

\section{REFERENCES}

BOLISANI E.; SCARSO E.; ZIEBA M. (2015) Emergent Versus Deliberate Knowledge Management Strategy: Literature Review and Case Study Analysis. 16th European Conference on Knowledge Management: ECKM 2015.

COSTA JUNIOR, M. P. (2014). Gestão de comunicações: aplicação do plano de gerenciamento das comunicações de projeto em um escritório de elaboração de projetos de Engenharia e Arquitetura. Revista Especialize On-line IPOG. $n^{\circ} 007$ Vol.01/2014.

DESHPANDEA, A. et al. (2014) A framework to leverage BIM for knowledge management in AEC projects. Creative Construction Conference 2014. 550-555.

JOBIM M. S. S.(1999) Controle do processo de projeto na construção civil. 1. ed. Porto Alegre: SENAI v. 1. 215p

KAMARA J. M. et al. (2002). Knowledge management in the architecture, engineering and construction industry, Construction Innovation. 53-67.

LOPES R. A. et al (2002). Gestão do fluxo de informações no processo de projeto: estudo de caso. Workshop Nacional Gestão Do Processo De Projeto Na Construção De Edifícios, Porto Alegre.

MUSZYNSKA, K. (2015). Communication management in project teams - Practices and patterns. Managing Intellectual Capital and Innovation for Sustainable and inclusive Society. 2015. 1359-1366.

NODARI, C. H. et al. (2015) Understanding the Path from Individual to Collective Leadership in Organisations through a Spiral of Knowledge Creation. Business Management Review (BMR), v. 4, p. 117-126, 2015.

OGBEIDE, E. (2010). State of the art report on the flow of information in a bridge life cycle. Master of Science Thesis in the Master's Programme Structural Engineering and Building Performance Design.Göteborg, Sweden.

OMOTAYO, F. O. (2015) Knowledge Management as an important tool in Organisational Management: A Review of Literature. University of NebraskaLincoln. Paper 1238. 5-23p.

PERMONIAN, R. R.; MARQUES NETO, J. C. (2015). Diagnóstico Da Gestão Dos Processos De Projetos De Arquitetura E Engenharia: Estudo De Caso Em Empresas De São Carlos-Sp XXXV Encontro Nacional De Engenharia De Produção Perspectivas Globais para a Engenharia de Produção Fortaleza, CE, Brasil, 13 a 16 de outubro de 2015. 
SCHERER, L. J.; KIRSTEN, T.; SANTOS, A. (2015). Possíveis falhas em gestão de projeto: um estudo sobre uma empresa de prestação de serviços. Simpósio Internacional de Gestão de Projetos, v. anais, p. 1-10, 2015.

SOUSA, C. R. (2010) Procedimentos de gestão da comunicação e informação para escritórios de arquitetura de pequeno porte. Dissertation (Master in Civil Construction). Universidade Federal do Paraná.114p.

SOUZA L. L. A.; AMORIM S. R. L. (2009). Avaliação do uso do BIM em escritórios de projeto. Gestão e Tecnologia de projetos. Vol.4, №2, 26-52.

STEHLING, M. P. (2012) A utilização de modelagem da informação da construção em empresas de arquitetura e engenharia de Belo Horizonte. Dissertation (Master in Civil Construction). Universidade Federal De Minas Gerais,165p.

TRIBELSKY, E.; SACKS, R. (2010a). The relationship between information flow and project success in multidisciplinary civil engineering design. Proceedings IGLC18,140-150.

TRIBELSKY, E.; SACKS, R. (2010b). Measuring information flow in the detailed design of construction projects. Research in Engineering Design.189- 206.

WHITE, M.; COHAN, A. (2016). A Guide to Capturing Lessons Learned. Available:https://www.conservationgateway.org/ConservationPlanning/partnering/cpc /Documents/Capturing_Lessons_Learned_Final.pdf Access:20/03/2016. 